\title{
Čtvrtživotní krize, její výskyt a prediktory u českých mladých dospělých
}

\section{Quarter-life crisis, its occurrence and predictors in Czech young adults}

\author{
Katarína Millová', Štěpánka Svárovská \\ 'Katedra psychologie, Filozofická fakulta, Ostravská \\ univerzita \\ 2 Psychologický ústav, Filozofická fakulta, Masarykova \\ univerzita
}

\begin{abstract}
Abstrakt Čtvrtživotní krize prožívaná v mladé dospělosti je oblastí v českém prostředí velmi málo prozkoumanou. Studie navazuje na model čtvrtživotní krize O. C. Robinsona. Cílem bylo prozkoumat výskyt čtvrtživotní krize a její prediktory u českých mladých lidí. Soubor tvořilo 393 lidí ve věku 21-30 let ( $M=24,87$ let; $S D=2,63$; 71 mužů (18 \%) a 322 žen (82 \%), u kterých bylo zjištováno prožívání čtvrtživotní krize (CSQ-9; Petrov, Robinson, \& Malinowski, 2019), sociální opora (MOS; Sherbourne \& Steward, 1991), finanční spokojenost (DŽS; Fahrenberg, Myrtek, Shumacher, \& Brähler, 2000) a strategie zvládání přechodu z adolescence do dospělosti (CSI-short; Tobin, 1995). Čtvrtživotní krizi prožívalo 50,7 \%; částečnou krizi prožívalo 26,3 \% a krizi neprožívalo 23 \% respondentů. Ženy prožívaly čtvrtživotní krizi častěji než muži; u vysokoškolsky vzdělaných pracujících lidí dosahovala nižší úrovně než u studujících (bez ohledu na vzdělání) a středoškolsky vzdělaných pracujících lidí. Výskyt čtvrtživotní krize u českých mladých lidí je podobný jako v dalších zemích, kde se čtvrtživotní krize již zkoumá. Mezi významné prediktory výskytu čtvrtživotní krize patřila nízká sociální opora a finanční spokojenost a větší využívání strategií zaměřených na emoce při zvládání přechodu z adolescence do dospělosti. Významným prediktorem byl i nižší věk, což odpovídá dvoufázovému průběhu čtvrtživotní krize.
\end{abstract}

Klíčová slova čtvrtživotní krize, finanční spokojenost, mladá dospělost, sociální opora, strategie zvládání stresu. 
Abstract Quarter-life crisis, which occurs during young adulthood (18-35 years; Robinson, 2019), is a phenomenon broadly discussed in both popular and scientific psychology but so far rather neglected in Czech psychological research. This crisis is connected to feelings of infinite possibilities, identity reappraisal, and inconsistency between accomplished life choices and subjective feelings of immaturity. The present study takes as its point of departure O. C. Robinson's model of quarter-life crisis, which describes two phases: the locked-out crisis, which occurs approximately in mid-twenties, and the locked-in crisis, which emerges at the beginning of thirties. Previous, mainly qualitative studies identified several factors contributing to the development of quarter-life crisis in an individual: lack of social support, financial dissatisfaction, and stressful life events (Atwood \& Scholtz, 2008; Stapleton, 2012; Wethington, Kessler, \& Pixley, 2004). Therefore, the study adopted a quantitative design and set out to examine the occurrence of quarter-life crisis and its predictors in Czech young people. The sample consisted of 393 people aged 21-30 years ( $M=24.87$ years; $S D=2.63 ; 71$ men (18 \%) and 322 women (82 \%), who completed an online questionnaire on quarter-life crisis (CSQ-9; Petrov et al., 2019), social support (MOS; Sherbourne \& Steward, 1991), financial satisfaction (DŽS; Fahrenberg et al., 2000), and strategies of coping with the transition from adolescence to adulthood (CSI-short; Tobin, 1995). The results indicated that $50.7 \%$ of respondents had fully experienced a quarter-life crisis; $26.3 \%$ of respondents had experienced a partial crisis, and $23 \%$ of respondents had not experienced a crisis. In addition, women experienced quarter-life crisis more often than men ( $t=3.06$; $d f=391 ; p<0.01$; Hedge's, $g=-0.40)$; people with university education had a lower level of quarter-life crisis (compared to high school with school-leaving exam educated people; $\left.F=6.29 ; d f=390 ; p<0.05 ; \eta_{\mathrm{p}}{ }^{2}=0.02\right)$ and so had lower level employed participants with university education compared to students (regardless of the level of education) and employed participants with high-school with school-leaving exam level of education ( $\left.F=4.35 ; d f=390 ; p<0.05 ; \eta_{\mathrm{p}}{ }^{2}=0.01\right)$. The occurrence of quarter-life crisis among Czech young people is similar to other countries where the phenomenon is already being studied. The results of the regression model showed that significant predictors of quarter-life crisis included low social support, low financial satisfaction, and more frequent use of strategies of coping with the transition from adolescence to adulthood oriented to emotions. Another significant predictor - lower age - corresponds with the two-phase model of the quarter-life crisis (Robinson, 2016, 2019), in which people experience the first phase (locked-out crisis) in their mid-twenties and the second phase (locked-in crisis) in their thirties. The only insignificant predictor was coping strategies oriented to the problem (adaptive and non-adaptive). A comparison of the three groups according to the level of quarter-life crisis - full quarter-life crisis, partial crisis, and absent crisis - showed that persons who experienced full quarter-life crisis and those with an absent quarter-life crisis differed in the levels of social support, financial satisfaction, coping strategies oriented to emotions, and gender. Other, less distinct groups in the level of crisis experience differed in lower financial satisfaction and more frequent use of strategies of coping with transition from adolescence to adulthood oriented to emotions (full crisis vs. partial crisis), and lower social support and more frequent use of non-adaptive 
ㅇ strategies of coping with transition from adolescence to adulthood oriented to emotions N (partial crisis vs. absent crisis).

กิ Keywords quarter-life crisis, financial satisfaction, young adulthood, social support, $\stackrel{N}{N} \quad$ coping strategies.

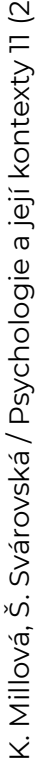


Čtvrtživotní krize' (quarter-life crisis) je fenomén, který je poměrně široce diskutován $\mathrm{v}$ zahraničních populárních médiích a dalších zdrojích zabývajících se vývojem v mladé dospělosti (Piskorz, 2018; Robbins \& Wilner, 2001; Schroeder, 2016). V odborném psychologickém výzkumu je mu věnována rostoucí pozornost především v britských a amerických studiích. Ty upozorňují na její závažnost zejména v souvislosti poměrně častými depresivními pocity, pocity nejistoty, úzkosti a jinou psychickou nepohodou nebo pocitovaným společenským tlakem, které se objevují u současné generace mladých dospělých a mohou negativně ovlivňovat jejich další psychosociální fungování (Aalto-Setälä, Poikolainen, Tuulio-Henriksson, Marttunen, \& Lönnqvist, 2009; Reinherz, Paradis, Giaconia, Stashwick, \& Fitzmaurice, 2003; Smith \& Blackwood, 2004). Existující modely jiných vývojových krizí (např. krize středního věku) a klasické modely vývoje zabývající se mladou dospělostí (např. Eriksonův nebo Levinsonův) však nejsou pro jejich zarámování př́liš̌ relevantní (Agarwal, Guntuku, Robinson, Dunn, \& Ungar, 2020; Erikson, 2002; Levinson, 1986; Robinson, 2016, 2019; Stapleton, 2012; Thorspecken, 2005). V českém odborném psychologickém výzkumu je zatím tato oblast spíše opomíjena (s výjimkou Millová, 2016; Zibrinyiová \& Ráczová, 2016). Proto se tato studie zaměřila na základní charakteristiky čtvrtživotní krize a jejich prediktory u českých mladých dospělých.

\section{Charakteristiky mladé dospělosti}

Mladá dospělost je vývojové období, pro které je charakteristické velké množství především společenských a interpersonálních změn. Ve srovnání s předešlými obdobími se zde naopak objevuje pouze minimum změn biologických - ty, které se objevují, jsou vysoce individuální (spojeny se životosprávou, těhotenstvím u žen atd.). Jde o období plné významných životních událostí: mladý člověk se osamostatňuje od rodičů, ukončuje proces vzdělávání, vstupuje do pravidelného zaměstnání, partnerského vztahu a zakládá vlastní rodinu. Události podobného významu se sice objevují v průběhu celého života, v mladé dospělosti je však jejich koncentrace nejvyšší (pro přehled Millová, 2020). Načasování těchto životních událostí se $\mathrm{v}$ posledních desetiletích mění, a to zejména v ekonomicky vyspělých zemích - naplňování „tradičních“ vývojových úkolů spojených s rodinou, výchovou dětí, ale i finanční nezávislostí se postupně posouvá do vyššího věku člověka a starší modely vývojových úkolů tak již nejsou zcela uplatnitelné (Havighurst, 1972; Nelson \& Luster, 2015). Zároveň se zejména v souvislosti s častějším vysokoškolských studiem u mladých lidí prodlužuje psychosociální moratorium, které bylo původně podle Eriksona (2002) charakteristické pro dřívější období adolescence. V návaznosti na tyto změny v první části mladé dospělosti popsal Arnett (2000) vynořující se dospělost, která je spojena se zkoumáním identity, pocitem životní nestability, prožíváním vývo-

V českých zdrojích se používají také označení krize rané dospělosti nebo krize mladého věku (Millová, 2016; Zibrinyiová \& Ráczová, 2016) 
jového mezidobí a nekonečnými životními možnostmi a obvykle se její znaky projevují u lidí v průběhu třetí dekády života. Souvisí nejenom s odkládáním vstupu do manželství nebo přijímáním dalších dospělých závazků, ale i s prodlužující se dobou vzdělávání. Přítomnost a projevy vynořující se dospělosti jsou závislé na kultuře a ekonomickém stavu společnosti; $\mathrm{v}$ českém prostředí se její charakteristiky projevují především u lidí ve věku 18 až 29 let (Macek et al., 2016).

\section{Čtvrtživotní krize}

Čtvrtživotní krize je vývojová krize, která se objevuje v období vynořující se dospělosti a je spojena především s přehodnocováním identity a dosavadních rozhodnutí. Tato krize souvisí s pocitem nadměrného množství př́ležitostí a s nesouladem mezi provedenými životními rozhodnutími a subjektivním pocitem osobní (ne)zralosti (Robinson \& Smith, 2010). Atwoodová a Scholtzová (2008) ji spojují především s pocity opuštěnosti, izolace, pochybováním o sobě a strachem $\mathrm{z}$ neúspěchu.

V návaznosti na Eriksonův model celoživotního vývoje (2002) popsal Robinson (Robinson \& Smith, 2010; Robinson, Wright, \& Smith, 2013) holistický model čtvrtživotní krize, který původně zahrnoval období 18 až 30 let. $\mathrm{V}$ rozsáhlém britském výzkumu mladých dospělých Robinson a Wright (2013) zjistili, že v tomto věku prožilo vývojovou krizi 39 \% mužů až 49 \% žen. Na základě Levinsonova modelu vývoje (1986) a výsledků pozdějších empirických výzkumů (Robinson, 2016, 2019; Robinson, Demetre, \& Litman, 2016; Robinson, Cimporescu, \& Thompson, 2020) byl model dále rozpracován do dvoufázové podoby a rozšiřil se také věkový rozsah možného výskytu krize až do poloviny čtvrté dekády života (přibližně do 35. roku života; Robinson, 2019). První fáze, tzv. vymknutí (locked-out), se objevuje především mezi 23 až 26 lety a její rozvoj souvisí s neschopností přijmout dospělé závazky. Druhá fáze, tzv. uzamčení (locked-in), se objevuje na konci třetí dekády života přibližně do 35 let a je spojena s neschopností vymanit se ze stávajících nevyhovujících závazků, jako je partnerský vztah nebo nevyhovující zaměstnání. Především první fáze vymknutí odpovídá charakteristikám rozšiřenějšího modelu vynořující se dospělosti (Arnett, 2000). Sami autoři čtvrtživotní krize považují svůj model spíše za doplnění stávající teorie vynořující se dospělosti, než za zcela odlišný přístup (Robinson, 2016; Robinson et al., 2020).

Přijetí modelu čtvrtživotní krize však není zcela jednoznačné, například Arnett (2010) ji kritizuje za přílišné zdůrazňování negativních změn spojených s počátkem mladé dospělosti. Další autoři dokonce zcela odmítají existenci čtvrtživotní krize vzhledem $\mathrm{k}$ tomu, že v průběhu mladé dospělosti dochází spíše k nárůstu sebehodnocení, osobní pohody a dalších pozitivních charakteristik (Galambos, Barker, \& Krahn, 2006; Rossi \& Mebert, 2011). Ačkoli je model čtvrtživotní krize některými autory kritizován, my jsme se na něj $\mathrm{v}$ naší studii zaměřili $\mathrm{z}$ důvodů její větší univerzálnosti, zejména vzhledem $\mathrm{k}$ úrovni vzdělání a pracovnímu statusu - ve srovnání s charakteristikami vynořující se dospělosti je podle výsledků dosavadních výzkumů mnohem méně navázána na vysokoškolské studium (Arnett, Kloep, Hendry, \& Tanner, 2011; Robinson \& Wright, 2013; Stapleton, 2012). 
Jednou $\mathrm{z}$ hlavních oblastí, na kterou jsme se $\mathrm{v}$ této studii zaměřili, byly prediktory čtvrtživotní krize. Studie Atwoodové a Scholtzové (2008) krizi spojuje především s pocity opuštěnosti, izolace, pochybováním o vlastní osobě a strachem $z$ neúspěchu. Stapletonová (2012) na základě kvalitativní analýzy rozhovorů s mladými lidmi identifikovala tři hlavní příčiny vzniku čtvrtživotní krize: 1) požadavky prostředí, očekávání od sebe sama i druhých lidí; 2) finanční otázky spojené s málo placenou nebo neuspokojující prací a 3) plytké sociální vztahy spojené s nedostatkem sociální opory. Mezi další významné zdroje čtvrtživotní krize mohou patřit významné životní události, které jsou spojené se změnou života v mladé dospělosti (odchod od rodičů, vstup do partnerského vztahu, manželství, vstup do zaměstnání atd.; pro přehled Millová, 2020). Pokud je člověk vnímá jako stresující, významně se mohou podílet na rozvoji krize (Wethington et al., 2004). Mezi takové body obratu patří i samotný přechod $\mathrm{z}$ adolescence do dospělosti, který je považován za první vývojovou tranzici v dospělém vývoji (Levinson, 1986).

Velká část dosavadního výzkumu čtvrtživotní krize ji studovala kvalitativním způsobem (Atwood \& Scholtz, 2008; Robinson, 2019; Robinson et al., 2013; Stapleton, 2012). Jelikož kvantitativních studií sledujících čtvrtživotní krizi a její souvislosti je zatím poměrně málo (viz Robinson et al., 2016; 2020), naše studie se zaměřila právě na její kvantitativní zachycení. V návaznosti na předešlé studie, jsme formulovali hlavní cíl naší studie, kterým bylo prozkoumat prediktory čtvrtživotni krize. Zaměřili jsme se na sociální oporu, finanční spokojenost a strategie zvládání přechodu $\mathrm{z}$ adolescence do dospělosti, které jsou v dosavadních studiích identifikovány jako významné zdroje jejího rozvoje (např. Atwood \& Scholz, 2008; Robinson et al., 2016; Stapleton, 2012). Zároveň jsme přihlédli $\mathrm{k}$ výsledkům předešlých studiích popisujících významný výskyt prožité vývojové krize u lidí ve věku 20-29 let (Robinson \& Wright, 2013) a věnovali se i jejímu výskytu u českých mladých dospělých. Ačkoli výzkumy sledující čtvrtživotní krizi v našem prostředí téměř neexistují, Macek, Bejček a Vaníčková (2007) popsali při výzkumu vynořující se dospělosti až u dvou třetin mladých Čechů problémy týkající se identity a přijímání dospělých závazků, což jsou charakteristiky typické právě pro první fázi čtvrtživotní krize - fázi vymknutí, které odpovídal věk našich respondenti̊.

\section{Metoda}

\section{Soubor}

Výzkumný soubor tvořilo 393 lidí (71 mužů a 322 žen) ve věku 21 až 30 let ( $M=24,87 ; S D=$ 2,63). Výzkum proběhl online formou v druhé polovině roku 2019 oslovením cílové skupiny respondentů přes sociální sítě (zejména Facebook), jednalo se tedy o přiležitostní výběr respondentů. Na začátku dotazníkové baterie byli participanti seznámeni s cíli a obsahem výzkumu; jejich účast na výzkumu byla dobrovolná, za svou účast nebyli finančně odměněni. Výzkum byl anonymní. Další charakteristiky souboru jsou zobrazeny v tabulce 1 . 
Tabulka 1

Charakteristiky souboru

\begin{tabular}{llllll} 
Charakteristiky & & $n$ & $\%$ & $M$ & $S D$ \\
\hline Věk & $21-30$ let & 393 & 100 & 24,87 & 2,63 \\
\hline \multirow{2}{*}{ Pohlaví } & Muži & 71 & 18,1 & & \\
& Ženy & 322 & 81,9 & \\
\hline \multirow{2}{*}{ Nejvyšší dosažené vzdělání } & Střední škola bez maturity a nižší & 3 & 0,8 \\
& Střední škola s maturitou & 130 & 33,1 \\
& Univerzita & 260 & 66,2 \\
\multirow{2}{*}{ Současný pracovní status } & Studující & 238 & 60,6 \\
& Pracující & 155 & 39,4 \\
\multirow{2}{*}{ Současný rodinný status } & Single & 339 & 86,3 & \\
& Partnerství/manželství & 53 & 13,4
\end{tabular}

\section{Použité metody}

Čtvrtživotní krize byla zjištována metodou Crisis Screening Questionnaire (CSQ-9; Petrov et al., 2019), která obsahuje 9 položek (hodnocených na dichotomní škále $n e=0$; $a n o=1$ ), ve kterých respondenti srovnávají proživání svého života v posledních 6 měsících se svým běžným dospělým životem (např̀ „Mám pocit, že můj život byl viditelně obtižnější, více stresující a náročnější než obvykle"). Dotazník byl přeložen pro potřeby stávající studie dvěma nezávislými překladateli do češtiny, po pilotním výzkumu $(n=20)$ byly provedeny drobné úpravy ve formulaci některých položek. Výsledky explorační i konfirmační faktorové analýzy podpořily jednodimenzionalitu metody, poukázaly však na jednu problematickou položku („Ve svém životě jsem si prošel/prošla zásadní změnou nebo se na blízkou změnu připravuji“), která významně snižovala i vnitřní konzistenci škály. Explorační faktorová analýza u kompletní škály ukázala, že tato položka měla zároveň i nižší faktorový náboj $(0,26)$. Průměrný faktorový náboj všech položek byl 0,55 a jediný faktor vysvětloval 32,14 \% rozptylu. Konfirmační faktorová analýza u plné škály s 9 položkami ukázala následující hodnoty: $\mathrm{X}^{2}(27)$ = 107,74; $p$ < 0,001; RMSEA = 0,10 (90 \% CI = 0,08; 0,12); SRMR = 0,06; GFI $=0,94 ; \mathrm{AGFI}=0,89 ; \mathrm{CFI}=0,86$. Po odstranění problematické položky byly výsledky explorační faktorové analýzy (jeden faktor vysvětloval 35,57 \% rozptylu; průměrný faktorový náboj byl 0,59) i konfirmační faktorové analýzy $\left(\mathrm{X}^{2}(20)=90,39 ; p<0,001\right.$; RMSEA = 0,08 $(90 \% \mathrm{CI}=0,06 ; 0,10)$; SRMR = 0,06; GFI = 0,94; AGFI = 0,90; CFI = 0,90) lepší. $\mathrm{Z}$ tohoto důvodu jsme v dalších analýzách pracovali se škálou CSQ-9 neobsahující tuto položku. Autoři (Petrov et al., 2019) uvádí cut-off skór pro různé úrovně prožívané čtvrtživotní krize: nepř́tomná krize (dosaženo méně než 33 \% hodnoty celkového skóru); částečně přítomná krize (mezi 33 \% a 66 \% hodnoty celkového skóru) a plně přitomná čtvrtživotní krize (více než $66 \%$ hodnoty celkového skóru).

Sociální opora byla měřena Dotazníkem sociální opory (MOS; Sherbourne $\&$ Steward, 1991; česká verze Kožený \& Tišanská, 2003), který obsahuje 19 položek hodnocených na 5bodové škále ( $1=n i k d y ; 5=v z ̌ d y)$ zahrnující tři dimenze sociální opory: chápající autoritu 
(sdílení času s blízkou osobou), emocionální blízkost (láska a intimní vztahy) a praktickou intervenci (materiální a praktická pomoc).

Finanční spokojenost byla zjištoována subškálou Finance z Dotazníku životní spokojenosti (DŽS; Fahrenberg et al., 2000; český překlad a úprava Rodná \& Rodný, 2001) obsahující 7 položek zjištujících spokojenost s vlastní finanční situací. Položky jsou hodnocené na 7 bodové škále $(1=$ velmi nespokojen $/ a ; 7=$ velmi spokojen $/ a)$.

Pro zjištění zvládání přechodu $z$ adolescence do dospělosti jsme použili zkrácenou verzi dotazníku Coping Strategies Inventory (CSI-short; Tobin, 1995; český překlad plné verze škály Balaštíková, Blatný, \& Kohoutek, 2004), která obsahuje 32 položek hodnocených na 5bodové škále ( 1 = vůbec nevystihuje mé chování; 5 = velmi vystihuje mé chování). Instrukce $\mathrm{u}$ metody popisující zátěžovou situaci byla upravena vzhledem $\mathrm{k}$ zaměření studie na přechod z adolescence do dospělosti: „Vzpomeňte si prosím, na období Vašeho přechodu $z$ adolescence do mladé dospělosti a na problémy a obtíže, které jste $v$ tomto období zažival/a." Metoda měří 8 primárních strategií zvládání, které se sdružují do strategií vyššího řádu, se kterými jsme pracovali v našem výzkumu: adaptivní copingové strategie zaměřené na problém (řešení problému, kognitivní restrukturace), adaptivní copingové strategie zaměřené na emoce (vyjádření emocí, sociální podpora), neadaptivní copingové strategie zaměřené na problém (vyhýbání se problému, fantazijní únik) a neadaptivní copingové strategie zaměřené na emoce (sociální izolace, sebeobviňování; Tobin, Holroyd, Reynolds, \& Wigal, 1989).

\section{Statistická analýza}

Celkově se výzkumu zúčastnilo 540 respondentů, do studie však byli zařazeni pouze respondenti, kteří vyplnili všechny části dotazníku. Dotazník finanční spokojenosti nebyl vyplněn zejména respondenty, kteři pouze studovali a sami si nepřivydělávali alespoň brigádou. Výsledný soubor $(n=393)$ tvořilo $72,78 \% \mathrm{z}$ původního souboru a významně se $\mathrm{v}$ sledovaných charakteristikách od vyřazených participantů nelišil. Základní hodnoty proměnných byly popsány na základě deskriptivní statistiky. Pro zjištění faktorové struktury metody CSQ-9 byla použita explorační faktorová analýza a konfirmační faktorová analýza s ukazateli chí kvadrát, RMSEA (Root Mean Square Error of Approximation) s 90\% intervalem spolehlivosti (CI), SRMR (Standardized Root Mean Squared Residual), CFI (Comparative Fix Index), GFI (Goodness-of-Fit Index) a AGFI (Adjusted Goodness-of-Fit Index). Rozdíly v čtvrtživotní krizi a v dalších proměnných (muži a ženy; single a v partnerství/manželství) byly zjištovány pomocí t-testu pro nezávislé výběry, jako ukazatel velikosti efektu bylo $\mathrm{z}$ důvodu velkého rozdílu ve velikosti souborů použito Hedgeovo g. Rozdíly v čtvrtživotní krizi (a v dalších proměnných) podle vzdělání a zaměstnání byly zjištovány na základě faktoriální ANOVY. Vztahy mezi proměnnými byly popsány na základě korelační a regresní analýzy, pro predikci plné, částečné nebo nepřítomné čtvrtživotní krize byla použita multinomiální logistická regresní analýza s poměrem šancí (odds ratio; OR) a 95\% intervalem spolehlivosti (CI). Deskriptivní statistiky, explorační faktorová analýza, korelační a regresní analýza a multinomiální logistická regresní analýza byly provedeny programem IBM SPSS verze 24 , konfirmační faktorová analýza byla provedena v programu STATISTICA verze $12 \mathrm{v}$ modulu Sepath. 


\section{Výsledky}

\section{Hodnoty sledovaných proměnných, jejich rozložení a vnitřní konzistence}

Deskriptivní charakteristiky čtvrtživotní krize, sociální opory, finanční spokojenosti a copingových strategií použitých při zvládání přechodu $\mathrm{z}$ adolescence do dospělosti jsou uvedeny v tabulce 2. Hodnoty šikmosti (vyšší než -0,67) a špičatosti (vyšší než -0,72) nenaznačují významné narušení normality (Kline, 2016). Vnitřní konzistence všech použitých škál byla dobrá až výborná (s výjimkou neadaptivních copingových strategií zaměřených na problém, které však dosahovaly hraniční hodnotu $\alpha=0,68)$. Čtvrtživotní krizi neprožívalo 90 respondentů (23\%), částečnou krizi prožívalo 104 respondentů (26,3 \%) a plnou čtvrtživotní krizi prožívalo 199 respondentů (50,7 \%). Ženy dosahovaly statisticky významně vyšší úrovně v prožívané čtvrtživotní krizi než muži $(t=3,06$; $d f=391 ; p<0,01 ;$ Hedgeovo $g=-0,40)$. Rozdíly v čtvrtživotní krizi u single lidí a lidí žijících v manželství nebo partnerství jsme nezjistili $(t=1,17 ; d f=391 ; p=0,24)$. Dále nás zajímala úroveň čtvrtživotní krize vzhledem $\mathrm{k}$ úrovni vzdělání a pracovního statusu. $\mathrm{Z}$ důvodu velmi nízkého počtu respondentů se středoškolským vzděláním bez maturity nebo nižším $(n=3)$, jsme tyto osoby z následující analýzy vyřadili a pracovali jsme pouze se dvěma skupinami úrovně vzdělání (středoškolské s maturitou a vysokoškolské). Výsledky 2 x 2 faktoriální ANOVY (vzdělání x pracovní status) ukázaly významný hlavní efekt vzdělání (vysokoškolsky vzdělaní lidé dosahovali nižší úrovně čtvrtživotní krize než středoškolsky vzdělaní; $F=6,29 ; d f=390 ; p<0,05 ; \eta_{\mathrm{p}}{ }^{2}=0,02$ ), hlavní efekt pracovního statusu významný nebyl, studující se od pracujících respondentů významně nelišili $(F=1,96$; $d f=390 ; p=0,16$ ). Interakční efekt (vzdělání x zaměstnání) poukázal na významné rozdíly: pracující lidé s vysokoškolským vzděláním prožívali významně nižší úroveň čtvrtživotní krize než další skupiny (pracující lidé se středoškolským vzděláním a studující lidé se SŠ/ VŠ vzděláním; $\left.F=4,35 ; d f=390 ; p<0,05 ; \eta_{\mathrm{p}}^{2}=0,01\right)$.

Tabulka 2

Deskriptivní charakteristiky proměnných $(n=393)$

\begin{tabular}{llllll} 
Charakteristiky & $M$ & $S D$ & $\alpha$ & šikmost & špičatost \\
\hline Čtvrtživotní krize & 5,12 & 2,20 & 0,73 & $-0,46$ & $-0,72$ \\
\hline Sociální opora & 73,58 & 14,56 & 0,96 & $-0,67$ & $-0,15$ \\
\hline Finanční spokojenost & 30,84 & 7,80 & 0,86 & $-0,30$ & $-0,34$ \\
\hline Adaptivní strategie - problém & 26,34 & 5,97 & 0,80 & $-0,30$ & $-0,23$ \\
\hline Adaptivní strategie - emoce & 24,64 & 6,80 & 0,82 & $-0,27$ & $-0,50$ \\
\hline Neadaptivní strategie - problém & 23,88 & 5,90 & 0,68 & $-0,11$ & $-0,44$ \\
\hline Neadaptivní strategie - emoce & 23,30 & 7,52 & 0,84 & 0,16 & $-0,62$
\end{tabular}

\section{Prediktory čtvrtživotní krize}

Základní vztahy mezi proměnnými jsme zjištovali pomocí korelační analýzy (s uplatněním Bonferroniho korekce; tabulka 3). Její výsledky ukazují významné vztahy se všemi proměnnými - sociální oporou, finanční spokojeností i strategiemi zvládání přechodu 
z adolescence do dospělosti, i když směr některých vztahů byl spíše neočekávaný (pozitivní korelace $\mathrm{s}$ adaptivními strategiemi zvládání vstupu $\mathrm{z}$ adolescence do dospělosti zaměřenými na emoce).

Tabulka 3

Korelační analýza - vztahy mezi proměnnými $(n=393)$

\begin{tabular}{|c|c|c|c|c|c|c|c|}
\hline Proměnná & 1 & 2 & 3 & 4 & 5 & 6 & 7 \\
\hline 1. Čtvrtživotní krize & - & & & & & & \\
\hline 2. Sociální opora & $-0,33^{* * *}$ & - & & & & & \\
\hline 3. Finanční spokojenost & $-0,33^{* * *}$ & $0,29 * * *$ & - & & & & \\
\hline 4. Adaptivní strategie - $\mathrm{P}$ & $-0,14^{*}$ & $0,21^{* * *}$ & $0,23 * * *$ & - & & & \\
\hline 5. Adaptivní strategie - E & $0,20 * * *$ & $0,17^{* *}$ & $-0,08$ & $-0,06$ & - & & \\
\hline 6. Neadaptivní strategie - $\mathrm{P}$ & $0,27^{* * *}$ & $-0,13$ & $-0,20 * * *$ & $-0,34^{* * *}$ & $0,16^{* *}$ & - & \\
\hline 7. Neadaptivní strategie - E & $0,45^{* * *}$ & $-0,30 * * *$ & $-0,29 * * *$ & $-0,23 * * *$ & $0,15^{*}$ & $0,45^{* * *}$ & - \\
\hline
\end{tabular}

Pozn. $\mathrm{P}=$ problém; $\mathrm{E}=$ emoce

${ }^{* * *} p<0,001 ;{ }^{* *} p<0,01 ;{ }^{*} p<0,05$ po uplatnění Bonferroniho korekce.

Následně jsme se zaměřili na prediktory čtvrtživotní krize s využitím regresní analýzy (tabulka 4). Celý model vysvětloval 33 \% variability rozptylu čtvrtživotní krize. V souladu s předešlými kvalitativními výzkumy byly sociální opora a finanční spokojenost významnými negativními prediktory - působily jako protektivní faktory proživání čtvrtživotní krize. Podobné výsledky se objevily u věku - čtvrtživotní krize se se vzrůstajícím věkem respondentů snižovala. Copingové strategie zvládání přechodu $\mathrm{z}$ adolescence do dospělosti zaměřené na problém významnými prediktory nebyly, copingové strategie zaměřené na emoce byly pozitivními prediktory čtvrtživotní krize (bez ohledu na jejich adaptivnost nebo neadaptivnost).

\section{Tabulka 4}

Regresni analýza - prediktory čtvrtživotní krize

\begin{tabular}{llll} 
& \multicolumn{3}{l}{ Úroveň čtvrtživotní krize } \\
Prediktor & $B$ & $S E$ & $\beta$ \\
\hline Sociální opora & $-0,04$ & 0,01 & $-0,24^{* * *}$ \\
\hline Finanční spokojenost & $-0,05$ & 0,01 & $-0,17^{* * *}$ \\
\hline Adaptivní strategie - problém & 0,02 & 0,02 & 0,06 \\
\hline Adaptivní strategie - emoce & 0,06 & 0,02 & $0,18^{* * *}$ \\
\hline Neadaptivní strategie - problém & 0,03 & 0,02 & 0,08 \\
\hline Neadaptivní strategie - emoce & 0,08 & 0,02 & $0,26^{* * *}$ \\
\hline Věk & $-0,12$ & 0,04 & $-0,14^{* * *}$ \\
\hline Celkové $R^{2}$ & $0,33^{* * *}$ & & \\
\hline$n$ & 393 & & \\
\hline
\end{tabular}

Pozn. ${ }^{* *} p<0,001$

Autoři metody hodnotící čtvrtživotní krizi (CSQ-9; Petrov et al., 2019) umožňují na základě cut-off skóru rozdělení míry prožívání čtvrtživotní krize na tři skupiny: nepřitomná 
krize, částečná krize a plně prožívaná čtvrtživotní krize. Pomocí multinomiální logistické regresní analýzy jsme zjištovali, zdali se jednotlivé skupiny mezi sebou významně liší $\mathrm{v}$ úrovni hodnot prediktorů čtvrtživotní krize (tabulka 5). Výsledky ukázaly významnost modelu: $\mathrm{X}^{2}(16)=116,00 ; p<0,001 ; R^{2}=0,28$ (Cox \& Snell); 0,32 (Nagelkerke). Lidé s plně prožívanou čtvrtživotní krizí měli nižší finanční spokojenost a více ke zvládání přechodu do dospělosti používali copingové strategie zaměřené na emoce (adaptivní i neadaptivní) než lidé s částečnou krizí. Lidé s částečně prožívanou čtvrtživotní krizí pocitovali nižší sociální oporu a více používali neadaptivní copingové strategie zaměřené na emoce při zvládání přechodu do dospělosti ve srovnání s lidmi s nepř́tomnou čtvrtživotní krizí. Nejvíc rozdílů se objevilo mezi skupinami plně prožívaná čtvrtživotní krize a nepřítomná čtvrtživotní krize: lidé s plnou krizí byli mladší, dosahovali nižší úrovně sociální opory i finanční spokojenosti; pro zvládání přechodu do dospělosti častěji využívali copingové strategie zaměřené na emoce (adaptivní i neadaptivní) a mnohem častěji do ní patřily ženy, ve srovnání se skupinou, která čtvrtživotní krizi neprožívala.

Tabulka 5

Míra proživání čtvrtživotní krize a její prediktory - multinomiální logistická regresní analýza

\begin{tabular}{|c|c|c|c|c|c|c|c|c|c|}
\hline \multirow[b]{2}{*}{ Prediktor } & \multicolumn{3}{|c|}{$\begin{array}{l}\text { Čtvrtživotní krize } \\
\text { vs. Částečná krize }\end{array}$} & \multicolumn{3}{|c|}{$\begin{array}{l}\text { Čtvrtživotní krize } \\
\text { vs. Nepřítomná krize }\end{array}$} & \multicolumn{3}{|c|}{$\begin{array}{l}\text { Částečná krize } \\
\text { vs. Nepřítomná krize }\end{array}$} \\
\hline & B & SE & $\begin{array}{l}\text { OR } \\
(95 \% \mathrm{CI})\end{array}$ & B & SE & $\begin{array}{l}\text { OR } \\
(95 \% \mathrm{CI})\end{array}$ & B & SE & $\begin{array}{l}\text { OR } \\
(95 \% \mathrm{CI})\end{array}$ \\
\hline $\begin{array}{l}\text { Sociální } \\
\text { opora }\end{array}$ & $-0,01$ & 0,01 & $\begin{array}{l}0,99 \\
(0,97 ; 1,01)\end{array}$ & $-0,05$ & 0,01 & $\begin{array}{l}0,95 * * * \\
(0,93 ; 0,98)\end{array}$ & $-0,04$ & 0,01 & $\begin{array}{l}0,96 * * \\
(0,94 ; 0,99)\end{array}$ \\
\hline $\begin{array}{l}\text { Finanční } \\
\text { spokojenost }\end{array}$ & $-0,03$ & 0,02 & $\begin{array}{l}0,96^{*} \\
(0,92 ; 0,99)\end{array}$ & $-0,05$ & 0,02 & $\begin{array}{l}0,96^{*} \\
(0,92 ; 0,99)\end{array}$ & $-0,01$ & 0,02 & $\begin{array}{l}0,99 \\
(0,95 ; 1,04)\end{array}$ \\
\hline $\begin{array}{l}\text { Adaptivní } \\
\text { strategie - P }\end{array}$ & 0,04 & 0,03 & $\begin{array}{l}1,04 \\
(0,99 ; 1,10)\end{array}$ & 0,04 & 0,03 & $\begin{array}{l}1,04 \\
(0,98 ; 1,10)\end{array}$ & 0,01 & 0,03 & $\begin{array}{l}1,00 \\
(0,95 ; 1,06)\end{array}$ \\
\hline $\begin{array}{l}\text { Adaptivní } \\
\text { strategie - E }\end{array}$ & 0,05 & 0,02 & $\begin{array}{l}1,05^{\star} \\
(1,00 ; 1,09)\end{array}$ & 0,07 & 0,03 & $\begin{array}{l}1,08 * * \\
(1,03 ; 1,13)\end{array}$ & 0,03 & 0,03 & $\begin{array}{l}1,03 \\
(0,98 ; 1,08)\end{array}$ \\
\hline $\begin{array}{l}\text { Neadaptivní } \\
\text { strategie - P }\end{array}$ & 0,04 & 0,03 & $\begin{array}{l}1,07 \\
(0,99 ; 1,13)\end{array}$ & 0,04 & 0,03 & $\begin{array}{l}1,04 \\
(0,97 ; 1,10)\end{array}$ & $-0,04$ & 0,03 & $\begin{array}{l}0,97 \\
(0,91 ; 1,03)\end{array}$ \\
\hline $\begin{array}{l}\text { Neadaptivní } \\
\text { strategie - E }\end{array}$ & 0,06 & 0,02 & $\begin{array}{l}1,07^{* *} \\
(1,02 ; 1,11)\end{array}$ & 0,12 & 0,03 & $\begin{array}{l}1,13 * * * \\
(1,07 ; 1,19)\end{array}$ & 0,06 & 0,03 & $\begin{array}{l}1,06^{*} \\
(1,00 ; 1,12)\end{array}$ \\
\hline $\begin{array}{l}\text { Ženy (vs. } \\
\text { muži) }\end{array}$ & 0,65 & 0,39 & $\begin{array}{l}1,91 \\
(0,90 ; 4,06)\end{array}$ & 0,63 & 0,42 & $\begin{array}{l}2,52^{*} \\
(1,10 ; 6,78)\end{array}$ & 0,28 & 0,40 & $\begin{array}{l}1,32 \\
(0,61 ; 2,88)\end{array}$ \\
\hline Věk & $-0,09$ & 0,05 & $\begin{array}{l}0,91 \\
(0,82 ; 1,01)\end{array}$ & $-0,13$ & 0,06 & $\begin{array}{l}0,88^{\star} \\
(0,78 ; 0,98)\end{array}$ & $-0,04$ & 0,06 & $\begin{array}{l}0,96 \\
(0,86 ; 1,08)\end{array}$ \\
\hline
\end{tabular}

Pozn. $R^{2}=0,28$ (Cox \& Snell); 0,32 (Nagelkerke). Model $\mathrm{X}^{2}(16)=116,00 ; p<0,001 ;{ }^{*} p<0,05 ;{ }^{*} p<0,01$; ${ }^{* * *} p<0,001$.

$O R=$ odds ratio; $S E$ = standardní chyba; $C I=$ interval spolehlivosti; $P=$ problém; $E=$ emoce; $d f=1$

\section{Post-hoc analýzy: rozdíly v dalších sledovaných charakteristikách}

Jelikož předešlé analýzy ukázaly významné rozdíly v úrovni prožívané čtvrtživotní krize u mužů a žen, ale i v souvislosti s úrovní vzdělání a pracovním statusem, zajímalo nás, zdali se v těchto skupinách objevují rozdíly kromě čtvrtživotní krize také v úrovni dalších sledovaných charakteristik, které jsme v studii sledovali. Výsledky t-testu pro nezávislé výběry ukázaly významné genderové rozdíly pouze $u$ sociální opory a $u$ adaptivních 
copingových strategií orientovaných na emoce, které dosahovaly vyšší úroveň u žen (sociální opora: $t=2,99 ; d f=391 ; p<0,01$; Hedgeovo $g=-0,40$; adaptivní strategie zvládání orientované na emoce: $t=4,91$; $d f=391$; $p<0,01$; Hedgeovo $g=-0,65$ ). V ostatních charakteristikách se ženy a muži nelišili (finanční spokojenost: $t=-1,63 ; d f=391 ; p=0,11$; adaptivní strategie zvládání orientované na problém: $t=-0,41 ; d f=391 ; p=0,69$; neadaptivní strategie zvládání orientované na problém: $t=0,94 ; d f=391 ; p=0,35$; neadaptivní strategie zvládání orientované na emoce: $t=1,60 ; d f=391 ; p=0,11)$.

Podobně jsme se v post-hoc analýzách zaměřili kroměčtvrtživotní krize také na rozdíly u dalších charakteristik vzhledem $\mathrm{k}$ úrovni vzdělání a pracovnímu statusu. Výsledky $2 \times 2$ faktoriální ANOVY (vzdělání x pracovní status) u sociální opory ukázaly významný hlavní efekt vzdělání (vyšší u lidí s vysokoškolským vzděláním; $F=8,88 ; d f=390 ; p<0,01$; $\eta_{\mathrm{p}}{ }^{2}=0,02$ ) a interakční efekt (vyšší u pracujících lidí s vysokoškolským vzděláním: $F=6,32$; $\left.d f=390 ; p<0,05 ; \eta_{\mathrm{p}}{ }^{2}=0,02\right)$. Hlavní efekt pracovního statusu významný nebyl $(F=0,06$; $d f=390 ; p=0,81)$. U využití neadaptivních strategií zvládání přechodu $\mathrm{z}$ adolescence do dospělosti (orientovaných na problém i na emoce) se projevil významně pouze hlavní efekt vzdělání (vyšší využití u lidí se středoškolským vzděláním; problém: $F=5,60 ; d f=$ 390; $p<0,05 ; \eta_{\mathrm{p}} 2=0,02$; emoce: $\left.F=6,02 ; d f=390 ; p<0,05 ; \eta_{\mathrm{p}}{ }^{2}=0,02\right)$. Hlavní efekt pracovního statusu (problém: $F=0,57 ; d f=390 ; p=0,45$; emoce: $F=0,57 ; d f=390 ; p=0,45$ ) ani interakční efekt (problém: $F=0,11 ; d f=390 ; p=0,74$; emoce: $F=1,09 ; d f=390 ; p=0,30$ ) významné nebyly. Naopak, u dalších sledovaných proměnných - finanční spokojenosti, adaptivních copingových strategií (orientovaných na problém i na emoce) jsme nezjistili žádné významné rozdíly: vzdělání (spokojenost: $F=0,29 ; d f=390 ; p=0,59$; adaptivní copingové strategie orientované na problém: $F=1,32 ; d f=390 ; p=0,25$; adaptivní copingové strategie orientované na emoce: $F=0,78 ; d f=390 ; p=0,38$ ), pracovní status (spokojenost: $F=1,90 ; d f=390 ; p=0,17$; adaptivní copingové strategie orientované na problém: $F=1,48$; $d f=390 ; p=0,23$; adaptivní copingové strategie orientované na emoce: $F=1,15 ; d f=390$; $p=0,29$ ), interakční efekt (spokojenost: $F=0,85 ; d f=390 ; p=0,36$; adaptivní copingové strategie orientované na problém: $F=0,26 ; d f=390 ; p=0,61$; adaptivní copingové strategie orientované na emoce: $F=2,68 ; d f=390 ; p=0,10$ ).

\section{Diskuse}

Tato studie se zaměřila na čtvrtživotní krizi a její prediktory u českých mladých dospělých. Jelikož jde v našem prostředí o téma empiricky velmi málo prozkoumané, zaměřili jsme se také na základní charakteristiky čtvrtživotni krize - její výskyt, genderové rozdíly a rozdíly vzhledem k vzdělání a pracovnímu statusu (studenti vs. pracující). Naše výsledky ukázaly, že plnou čtvrtživotní krizi prožívala celá polovina respondentů (50,7 \%), což je velmi podobný výsledek, jako zjistil v britském výzkumu Robinson (2016). Tato zjištění jsou o to více alarmující vzhledem $\mathrm{k}$ tomu, že dosavadní výzkum upozorňuje na poměrně časté depresivní pocity nebo jinou psychickou nepohodu prožívané v období první části mladé dospělosti (Aalto-Setälä et al., 2009; Reinherz et al., 2003; Smith \& Blackwood, 2004). Vyšší úroveň proživané čtvrtživotní krize u žen rovněž koresponduje s předešlými studi- 
emi, které popsali její častější výskyt právě u žen (Robinson \& Wright, 2013). V návaznosti na tyto genderové rozdíly je očekávatelné, aby se v post-hoc testech projevily významné rozdíly u sledovaných prediktorů krize v prospěch mužů. Výsledky post-hoc analýz však ukázaly, že naopak ženy pocitují vyšší úroveň sociální opory a více využívají adaptivní strategie zvládání při přechodu $\mathrm{z}$ adolescence do dospělosti orientované na emoce. Zjištěné výsledky bychom tedy mohli vztáhnout spíše k emotivitě obecně, která je pro prožívání jakékoli životní krize obvyklá (zejména negativní emotivita) - tu jsme v naší studii jako prediktor nesledovali. Existující studie zabývající se čtvrtživotní krizí však potvrdily jejich významné propojení (Robinson, 2019; Robinson et al., 2020). Výsledky studií sledujících emotivitu u mladých dospělých obecně opakovaně poukazují na vyšší úroveň negativní emotivity (depresivita, úzkost) u žen, především v první části třetí dekády života (Beiter et al., 2015; Galambos et al., 2006) a právě její vyšší úroveň může souviset s intenzivnějším proživáním krize navzdory větší sociální opoře.

Dále jsme se zaměřili na rozdíly v čtvrtživotní krizi vzhledem k vzdělání a pracovnímu statusu. Jelikož jsme sledovali i jejich interakční efekt, umožnilo nám to srovnání nejenom studentů a pracujících lidí nebo vysokoškolsky a středoškolsky vzdělaných lidí, ale i identifikaci pracujících, kteří vysokou školu nikdy nestudovali. Zjištěné výsledky ukázaly nižší úroveň čtvrtživotní krize u lidí s vysokoškolským vzděláním (ve srovnání se stř̌edoškolským vzděláním s maturitou), a také nižší úroveň u pracujících lidí s vysokoškolským vzděláním ve srovnání se studujícími (bez ohledu na výši vzdělání) a pracujícími lidmi se středoškolským vzděláním. Tyto výsledky se poněkud odlišují od předešlých studií, které přímý vztah čtvrtživotní krize a výše vzdělání nepotvrdily (Robinson \& Wright, 2013; Stapleton, 2012). Zjištěné rozdíly souvisí podle nás se dvěma důvody: lidé se středoškolským vzděláním měli v našem souboru často nižší věk (šlo o vysokoškolské studenty) naše následné analýzy ukazují, že úroveň prožívané čtvrtživotní krize s rostoucím věkem v průběhu třetí dekády života klesá. Druhým možným vysvětlením jsou zdroje, ze kterých vysokoškolsky vzdělaní lidé (pracující) čerpají - podle výsledků našich post-hoc analýz dosahovali vyšší úrovně sociální opory a méně často používali neadaptivní strategie zvládání přechodu $\mathrm{z}$ adolescence do dospělosti. Navíc, dosavadní výzkum sledující psychosociální souvislosti vzdělání ukazuje, že vyšší vzdělání je spojeno s lepším duševním zdravím a pozitivním psychosociálním fungováním obecně (pro přehled např. Niemeyer, Bieda, Michalak, Schneider, \& Margraf, 2019). Na rozdíl od studií sledujících aspekty vynořující se dospělosti (např. Arnett et al., 2011) naše výsledky nepropojily jednoznačně čtvrtživotní krizi s prací nebo studiem obecně, jelikož z tohoto hlediska se naši participanti v její úrovni nelišili.

V návaznosti na předešlé empirické studie a vývojové modely (Atwood \& Scholtz, 2008; Erikson, 2002; Levinson, 1986; Robinson, 2016; Stapleton, 2012) jsme mezi prediktory čtvrtživotní krize zařadili věk, sociální oporu, finanční spokojenost a strategie zvládání využívané při vstupu z adolescence do dospělosti. Mezi významné prediktory patřily sociální opora a finanční spokojenost, které plnily roli protektivních faktorů - lidé prožívající vyšší sociální oporu a spokojení s vlastní finanční situací dosahovali nižší úrovně prožívané čtvrtživotní krize. Tyto výsledky navazují na předešlé výzkumy Atwoodové 
a Scholtzové (2008) a Stapletonové (2012), které je identifikují jako klíčové faktory rozvoje nebo nepřítomnosti čtvrtživotní krize, ale i dalších výzkumů, které spojují sociální oporu s lepším duševním i fyzickým zdravotním stavem a finanční samostatnost se znaky dosažené dospělosti (Ježek, Macek, Bouša, \& Kvitkovičová, 2016; Rossi \& Mebert, 2011; Uchino, 2009). Negativní vztah s věkem je vzhledem k věkovému rozmezí našeho souboru a dvoufázovému modelu čtvrtživotní krize očekávatelný - mladší participanti spíše prožívají první fázi čtvrtživotní krize (fáze vymknutí), starší participanti jí majíjiž nejspíš za sebou, ještě do druhé fáze nevstoupila (fáze uzamčení; Robinson, 2016, 2019). Méně očekávané výsledky se objevily u strategií zvládání přechodu $\mathrm{z}$ adolescence do dospělosti. Zatímco strategie zaměřené na problém měly velmi slabý nebo žádný vztah se čtvrtživotní krizí, strategie zaměřené na emoce prokázaly významnou pozitivní souvislost u neadaptivních, ale i u adaptivních strategií. Pozitivní vztah neadaptivních strategií zvládání a prožívané čtvrtživotní krize je očekávatelný, jelikož i předešlý výzkum opakovaně poukázal na souvislost neadaptivního zvládání stresu a následné zvýšené negativní emocionality nebo problémů spojených s identitou, které jsou pro čtvrtživotní krizi charakteristické (Berzonsky, 1992; Kelly, Sereika, Battista, \& Brown, 2007; Luyckx, Klimstra, Duriez, Schwartz, \& Vanhalst, 2012). Neočekávaným výsledkem byl pozitivní vztah prožívané čtvrtživotní krize a adaptivních strategií zvládání využitých při přechodu $\mathrm{z}$ adolescence do dospělosti. Mezi ně patřily také strategie spojené s vyjádřením emocí. Výsledky některých studií ukazují, že za určitých okolností může být zejména jejich ne zcela regulované vyjádření spíše neadaptivní strategií (např. Kennedy-Moore $\&$ Watson, 2001). Podobně obsahově vymezena byla strategie vyjádření emocí i v našem výzkumu („Neovládl/a jsem se“; „Moje city mne zcela ovládly“ atd.) a jejich neadaptivní vnímání se projevilo i významnými pozitivními korelacemi s oběma typy neadaptivních strategií zvládání $(r=0,15-0,16)$.

Ačkoli všechny sledované proměnné (kromě strategií zvládání zaměřených na problém) byly významnými prediktory čtvrtživotní krize, jejich význam se lišil vzhledem $\mathrm{k}$ úrovni prožívané krize. Největší rozdíl v prediktorech (nižší sociální opora a finanční spokojenost, vyšší využití strategií zvládání orientovaných na emoce u přechodu do dospělosti, nižší věk a ženské pohlaví) se projevil u srovnání dvou krajních skupin lidí, kteří prožívali plnou čtvrtživotní krizi a lidí s nepřítomnou čtvrtživotní krizí. Další, v proživání čtvrtživotní krize méně odlišné skupiny, se od sebe lišily nižší finanční spokojeností a vyšším využitím strategií zvládání zaměřených na emoce (plná krize vs. částečná krize) a nižší sociální oporou a vyšším využitím neadaptivních strategií zvládání zaměřených na emoce (částečná krize vs. nepřítomná krize).

\section{Limity výzkumu}

Zjištěné výsledky mohly být ovlivněny několika faktory, mezi nejdůležitější z nich patřily vlastnosti výzkumného souboru a charakteristiky použitých metod. Jelikož výzkum probíhal online formou, u souboru se objevují vlastnosti charakteristické pro online sběr dat, zejména vyšší podíl vysokoškolsky vzdělaných lidí a větší zastoupení žen. Výsledná zjištění tak nelze zobecnit na obecnou populaci lidí v mladé dospělosti. Vzhledem k věkovému rozpětí souboru (mezi 21 a 30 lety) jsme navíc byli schopni zachytit především první 
fázi čtvrtživotní krize, tzv. vymknutí (Robinson, 2016; 2019), pro zachycení čtvrtživotní krize v celém rozsahu by náš soubor musel být věkově mnohem širší. Další omezení studie vycházela $\mathrm{z}$ použitých metod, především u metody CSI měřící strategie zvládání. Ačkoli jsou strategie rozdělovány na adaptivní a neadaptivní (př́klonové a odklonové; Tobin, 1995), především formulace některých adaptivních strategií zaměřených na emoce neimplikuje vždy adaptivní zvládnutí zátěžové situace („Neovládl/a jsem se“; „Moje city mne zcela ovládly“ atd.), což se projevilo i v našem výzkumu. Naopak, některé neadaptivní strategie orientované na problém mohou být za určitých okolností vnímány jako konstruktivní (např. strategie sebeobviňování v situaci, která je opravdu zapř́činěná respondentem). $\mathrm{V}$ našem výzkumu jsme se navíc zaměřili pouze na jedinou náročnou situaci spojenou se začátkem mladé dospělosti - na přechod $z$ adolescence do dospělosti. V tomto období se však člověk může setkat s mnoha jinými životními událostmi - at' už věkově-normativními (např. ukončení studia, začátek řádného zaměstnání, odstěhování se od rodičů) nebo velice individuálními, které významně ovlivňují prožívání čtvrtživotní krize (Robinson et al., 2020). Přítomnost dalších náročných životních událostí tak mohla ovlivnit kvalitu prožívání i úroveň čtvrtživotní krize i u participantů v našem souboru, zejména pokud se objevily předčasně (u věkově-normativních událostí) nebo byl jejich výskyt př́liš koncentrovaný.

\section{Závĕr}

Tato studie se zabývala charakteristikami čtvrtživotní krize a jejími prediktory u českých mladých dospělých. Její výskyt i genderové rozdíly odpovídají dosavadním, především britským a americkým výzkumům u mladých dospělých. Jelikož řada $\mathrm{z}$ nich přistupovala ke studiu čtvrtživotní krize kvalitativním způsobem, naše studie poskytuje odlišný pohled na tuto problematiku. Důležité je zmínit, že výzkum probíhal v druhé polovině roku 2019 před propuknutím pandemie COVID-19, hodnocení prožívání života v posledních 6 měsících tedy nebylo ovlivněno touto společensky i individuálně neobvyklou a stresující situací. Následující výzkum čtvrtživotní krize by se mohl u věkově širšího, genderově a vzdělanostně více vyrovnaného souboru zaměřit na potvrzení (nebo vyvrácení) dvoufázové struktury modelu čtvrtživotní krize, tak, jak ji v novějších studiích formuloval Robinson (2016; 2019). To jsme vzhledem $k$ věkovému rozložení našeho souboru nemohli provést. $V$ naší studii jsme také vzhledem $k$ věkovému rozsahu cílového souboru nezjištovali, zdali respondenti měli děti nebo byli bezdětní. Přítomnost dítěte je podle výsledků výzkumu Robinsona a Wrighta (2013) jedním $\mathrm{z}$ faktorů, které mohou vést ke snížení intenzity prožívání čtvrtživotní krize. Další výzkum by se proto mohl zaměřit také na srovnání bezdětných mladých lidí a jejich vrstevníků, kteří již založili vlastní rodinu. Následující studie by se kromě identifikace dalších prediktorů čtvrtživotní krize měly zaměřit i na možnosti jejího řešení, vzhledem $\mathrm{k}$ tomu, že důsledky čtvrtživotní krize mohou ovlivňovat život člověka po velkou část jeho mladé dospělosti (pro nástin možností řešení v oblasti poradenství viz Stapleton, 2012). 
Aalto-Setälä, T., Poikolainen, K., Tuulio-Henriksson, A., Marttunen, M., \& Lönnqvist, J. (2009). Predictors of mental distress in early adulthood: a five-year follow-up of 709 high-school students. Nordic Journal of Psychiatry, 56(2), 121-125. https://doi.org/10.1080/080394802753617935

Agarwal, S., Guntuku, S. C., Robinson, O. C., Dunn, A., \& Ungar, L. H. (2020). Examining the phenomenon of quarter-life crisis through artificial intelligence and the language of Twitter. Frontiers in Psychology, 11, 341. https://doi.org/10.3389/fpsyg.2020.00341

Arnett, J. J. (2000). Emerging adulthood: A theory of development from the late teens through the twenties. American Psychologist, 55(5), 469-480. https://doi.org/10.1037/0003-066X.55.5.469

Arnett, J. J. (2010). Oh, grow up! Generational grumbling and the new life stage of emerging adulthood - Commentary on Trzesniewski \& Donnellan (2010). Perspectives on Psychological Science, 5(1), 89-92. https://doi.org/10.1177/1745691609357016

Arnett, J. J., Kloep, M., Hendry, L. B., \& Tanner, J. L. (2011). Debating emerging adulthood: Stage or process?. New York: Oxford University Press.

Atwood, J. D., \& Scholtz, C. (2008). The quarter-life time period: An age of indulgence, crisis or both?. Contemporary Family Therapy, 30(4), 233-250. https://doi.org/10.1007/S10591-008-9066-2

Balaštíková, V., Blatný, M., \& Kohoutek, T. (2004). Aspekty sebepojetí jako determinanty výběru strategií zvládání u adolescentů. Československá psychologie, 48(5), 410-415.

Beiter, R., Nash, R., McCrady, M., Rhoades, D., Linscomb, M., Clarahan, M., \& Sammut, S. (2015). The prevalence and correlates of depression, anxiety, and stress in a sample of college students. Journal of Affective Disorders, 173, 90-96. https://doi.org/10.1016/j.jad.2014.10.054

Berzonsky, M. D. (1992). Identity style and coping strategies. Journal of Personality, 60(4), 771-788. https://doi.org/10.1111/j.1467-6494.1992.tb00273.x

Erikson, E. H. (2002). Dětství a společnost. Praha: Argo.

Fahrenberg, J., Myrtek, M., Schumacher, J., \& Brähler, E. (2000). Fragebogen zür Lebenszufriedenheit (FLZ). Handanweisung. Göttingen: Hogrefe.

Galambos, N. L., Barker, E. T., \& Krahn, H. J. (2006). Depression, self-esteem, and anger in emerging adulthood: seven-year trajectories. Developmental Psychology, 42(2), 350-365. https://doi. org/10.1037/0012-1649.42.2.350

Havighurst, R. J. (1972). Developmental tasks and education (3. vydání). New York: McKay.

Ježek, S., Macek, P., Bouša, O., \& Kvitkovičová, L. (2016). Přechod do dospělosti (s. 9-22). In L. Lacinová, S. Ježek, \& P. Macek (eds.), Cesty do dospělosti: Psychologické a sociální charakteristiky dnešních dvacátníků. Brno: Masarykova univerzita.

Kelly, M. A. R., Sereika, S. M., Battista, D. R., \& Brown, C. (2007). The relationship between beliefs about depression and coping strategies: Gender differences. British Journal of Clinical Psychology, 46(3), 315-332. https://doi.org/10.1348/014466506X173070

Kennedy-Moore, E., \& Watson, J. C. (2001). How and when does emotional expression help? Review of General Psychology, 5(3), 187-212. https://doi.org/10.1037/1089-2680.5.3.187

Kline, R. B. (2016). Principles and practice of structural equation modelling (4. vydání). New York: The Guilford Press.

Kožený, J., \& Tišanská, L. (2003). Dotazník sociální opory - MOS: Vnitřní struktura nástroje. Československá psychologie, 47(2), 135-143.

Levinson, D. J. (1986). A conception of adult development. American Psychologist, 41(1), 3-13. https:// doi.org/10.1037/0003-066X.41.1.3

Luyckx, K., Klimstra, T. A., Duriez, B., Schwartz, S. J., \& Vanhalst, J. (2012). Identity processes and coping strategies in college students: short-term longitudinal dynamics and the role of personality. Journal of Youth and Adolescence, 41(9), 1 226-1 239. https://doi.org/10.1007/s10964-012-9753-z 
Macek, P., Bejček, J., \& Vaníčková, J. (2007). Contemporary Czech emerging adults. Journal of Adolescent Research, 22(5), 444-475. https://doi.org/10.1177/0743558407305417

Macek, P., Ježek, S., Lacinová, L., Bouša, O., Kvitkovičová, L., Neužilová Michalčáková, R., \& Širůček, J. (2016). Emerging adults in the Czech Republic: Views into and across different domains of life (s. 175-201). In R. Žukauskiené (ed.), Emerging adulthood in a European context. Oxon \& New York: Routledge.

Millová, K. (2016). Mladá dospělost. In M. Blatný (ed.), Psychologie celoživotního vývoje (s. 117-140). Praha: Karolinum.

Millová, K. (2020). Životní tranzice v dospělosti z pohledu životní dráhy: přehledová studie. Psychologie a její kontexty, 11(1), 5-22. https://doi.org/10.15452/PsyX.2020.11. 0001

Nelson, L. J., \& Luster, S. S. (2015). „Adulthood“ by whose definition?: The complexity of emerging adults' conceptions of adulthood. In J. J. Arnett (ed.), The Oxford handbook of emerging adulthood (s. 421-437). New York: Oxford University Press.

Niemeyer, H., Bieda, A., Michalak, J., Schneider, S., \& Margraf, J. (2019). Education and mental health: Do psychosocial resources matter?. SSM - Population Health, 7, 100392. https://doi.org/10.1016/j. ssmph.2019.100392

Petrov, N., Robinson, O.C., \& Malinowski, J. (2019, květen). What do dreams really mean? The relationship between dream content, age, recent experienced emotions and crisis episodes in adults. Př́ispěvek prezentován na Annual British Psychological Society Conference, Harrogate, United Kingdom.

Piskorz, J. (2018). Me and my quarter-life crisis: A millennial asks what went wrong. The Guardian. Získáno $\mathrm{z}$ https://www.theguardian.com

Reinherz, H. Z., Paradis, A. D., Giaconia, R. M., Stashwick, C. K., \& Fitzmaurice, G. (2003). Childhood and adolescent predictors of major depression in the transition to adulthood. American Journal of Psychiatry, 160(12), 2 141-2 147. https://doi.org/10.1176/appi.ajp.160.12.2141

Robbins, A., \& Wilner, A. (2001). Quarterlife crisis: The unique challenges of life in your twenties. New York: J. P. Tarcher/Putnam.

Robinson, O. C. (2016). Emerging adulthood, early adulthood and quarter-life crisis: Updating Erikson for the twenty-first century (s. 17-30). In R. Žukauskiené (ed.), Emerging adulthood in a European context. Oxon \& New York: Routledge.

Robinson, O. C. (2019). A longitudinal mixed-methods case study of quarter-life crisis during the post-university transition: Locked-out and locked-in forms in combination. Emerging Adulthood, 7(3), 167-179. https://doi.org/10.1177/2167696818764144

Robinson, O. C., Cimporescu, M., \& Thompson, T. (2020). Wellbeing, developmental crisis and residential status in the year after graduating from higher education: A 12-month longitudinal study. Journal of Adult Development. Advance online publication. https://doi.org/10.1007/s10804-02009361-1

Robinson, O. C., Demetre, J. D., \& Litman, J. A. (2016). Adult life stage and crisis as predictors of curiosity and authenticity: Testing inferences from Erikson's lifespan theory. International Journal of Behavioral Development, 41(3), 426-431. https://doi.org/10.1177/0165025416645201

Robinson, O. C., \& Smith, J. A. (2010). Investigating the form and dynamics of crisis episodes in early adulthood: The application of a composite qualitative method. Qualitative Research in Psychology, 7(2), 170-191. https://doi.org/10.1080/14780880802699084

Robinson, O. C., \& Wright, G. R. T. (2013). The prevalence, types and perceived outcomes of crisis episodes in early adulthood and midlife. International Journal of Behavioral Development, 37(5), 407-416. https://doi.org/10.1177/0165025413492464

Robinson, O. C., Wright, G. R. T., \& Smith, J. A. (2013). The holistic phase model of early adult crisis. Journal of Adult Development, 20(1), 27-37. https://doi.org/10.1007/s10804-013-9153-y

Rodná, K., \& Rodný, T. (2001). Dotazník životní spokojenosti. Praha: Testcentrum.

Rossi, N. E., \& Mebert, C. J. (2011). Does a quarterlife crisis exist?. The Journal of Genetic Psychology: 
Research and Theory on Human Development, 172(2), 141-161. https://doi.org/10.1080/00221325.201 0.521784

Schroeder, J. (2016, záŕí). Millennials, this is what your quarter-life crisis is telling you. Forbes. Získáno z https://www.forbes.com

Sherbourne, C. D., \& Stewart, A. L. (1991). The MOS social support survey. Social Science \& Medicine, 32(6), 705-714. https://doi.org/10.1016/0277-9536(91)90150-B

Smith, D. J., \& Blackwood, D. H. R. (2004). Depression in young adults. Advances in Psychiatric Treatment, 10(1), 4-12. https://doi.org/10.1192/apt.10.1.4

Stapleton, A. (2012). Coaching clients through the quarterlife crisis: What works? International Journal of Evidence Based Coaching and Mentoring, Special Issue, 6, 130-145.

Thorspecken, J. M. (2005, květen). Quarterlife crisis: The unaddressed phenomenon. Př́spěvek prezentován na Annual Conference of the New Jersey Counseling Association (s. 120-127). New Jersey. Získáno z http://citeseerx.ist.psu.edu/viewdoc/download?doi=10.1.1.477.3573\&rep=repl\&type=pdf\#page=121

Tobin, D. L. (1995). Scoring information for the CSI-S. Ohio: University of Ohio.

Tobin, D. L., Holroyd, K. A., Reynolds, R. V., \& Wigal, J. K. (1989). The hierarchical factor structure of the Coping Strategies Inventory. Cognitive Therapy and Research, 13(4), 343-361. https://doi. org/10.1007/BF01173478

Uchino, B. N. (2009). Understanding the links between social support and physical health: a lifespan perspective with emphasis on the separability of perceived and received support. Perspectives in Psychological Science, 4(3), 236-255. https://doi.org/10.1111/j.1745-6924.2009.01122.x

Wethington, E., Kessler, R. C., \& Pixley, J. E. (2004). Turning points in adulthood. In O. G. Brim, C. D. Ryff, \& R. C. Kessler (eds.), How healthy are we? A national study of well-being at midlife (s. 586-613). Chicago: The University of Chicago Press.

Zibrinyiová, V., \& Ráczová, B. (2016). Kríza mladého veku - nový fenomén? Psychologie a její kontexty, $7(2), 3-14$.

Korespondenční autorka: Katarína Millová, Katedra psychologie, Filozofická fakulta,

Ostravská univerzita, Reální 5, 70103 Ostrava, Česká republika.

Email: katarina.millova@osu.cz

Millová, K., \& Svárovská, Š. (2020). Čtvrtživotní krize, její výskyt a prediktory u českých mladých dospělých Psychologie a její kontexty, 17(2), 73-90. https://doi.org/10.15452/PsyX.2020.11.0011 